\title{
Joseph H. Greenberg
}

PAUL NEWMAN

Joseph H. Greenberg, undoubtedly the most important African linguist in the second half of the 20th century, passed away on May 7, 2001. Greenberg was born in Brooklyn, New York, on May 28, 1915. He received his B.A. (Phi Beta Kappa) from Columbia University in 1936, and his Ph.D. in anthropology from Northwestern University in 1940. His Ph.D. thesis was on traditional, non-Islamic Hausa religion.

During World War II (1940-1945), he served in the United States Army Signal and Intelligence Corps. After the war, he spent a year on a Social Science Research Council Fellowship and then took a teaching position in Anthropology at the University of Minnesota (1946-48). This was followed by an appointment at Columbia University (1948-62). While at Columbia, he served for five years as coeditor of the journal Word. In 1962 Greenberg moved to Stanford University, where he was Professor of Anthropology and Linguistics. He officially retired from Stanford in 1985, but remained professionally active until the time of his death.

Greenberg was an unusually prolific and wide-ranging scholar with some 250 publications to his credit. His initial reputation was established through his monumental work in the area of African linguistic classification. This was published first as a series of articles in the late 1940s and then ultimately in reworked and revised form as The Languages of Africa (1963), a work that thirty-five or more years later still stands as the cornerstone of African language classification. In his work, Greenberg dismantled the then standard classification of Meinhof and assigned all of the languages of Africa into one of four phyla: Afroasiatic (which did away with the distinction between Semitic and so-called "Hamitic"), NigerCongo (= Niger-Kordofanian) (which incorporated Bantu as a lower-level constituent), Nilo-Saharan (the most contentious of his groupings, which contained languages as distant as Songhai and Maasai), and Khoisan (which combined the former "Bushman" and "Hottentot" languages as well as the Tanzanian outliers Sandawe and Hadza).

Greenberg also provided original classifications in other geographical areas as well, most notably his controversial Native American classification (see Language 
in the Americas, Stanford University Press (1987)), and his recent large-scale grouping of the languages of Europe and Asia (see Indo-European and Its Closest Relatives: The Eurasiatic Language Family, Stanford University Press (2000)). In addition, he made major contributions to the theory and methodology of classification. Apart from language family classification, Greenberg is best known for his groundbreaking work in the fields of language typology and language universals (see Universals of Language, ed. by J. H. Greenberg, MIT Press (1963)).

Throughout his career, Greenberg received numerous honors. He was awarded the Haile Selassie Prize for African Research (1967) and the Talcot Parsons Prize for Social Sciences (given by the American Academy of Arts and Sciences, 1996). He received three separate Guggenheim fellowships and was invited twice to be a fellow of the Center for Advanced Studies in the Behavioral Sciences. He was an elected member of the National Academy of Sciences, the American Academy of Arts and Sciences, and the American Philosophical Society, and was the First Distinguished Lecturer of the American Anthropological Association. He held the office of President of the Linguistic Society of America, of the African Studies Association, and of the West African Linguistic Society.

Greenberg was honored by two festschrifts: Linguistic Studies Offered to Joseph Greenberg on the Occasion of his Sixtieth Birthday, 2 vols., ed. by Alphonse Juilland, Anma Libri (1976-1977), and Studies in Typology and Diachrony: Papers Presented to Joseph Greenberg on his 75th Birthday, ed. by William Croft, Keith Denning, and Suzanne Kemmer, Benjamins (1990), and by the publication of two collections of his articles: Language, Culture, and Communication: Essays by Joseph H. Greenberg, ed. by Anwar S. Dil, Stanford University Press (1971), and On Language: Selected Writings of Joseph H. Greenberg, ed. by Keith Denning and Suzanne Kemmer, Stanford University Press (1990).

Greenberg's own thoughts about his intellectual approach can be found in his "On being a linguistic anthropologist," Annual Review of Anthropology 15: 1-24 (1986), "The influence of WORD and the Linguistic Circle of New York on my intellectual development." Word 45: 19-25 (1994), and in Paul Newman, "An interview with Joseph Greenberg," Current Anthropology 32: $453-67$ (1991).

Indiana University

\section{Bibliography of Greenberg's Writings on African Languages and Cultures}

\section{Books and Articles}

1940a. The decipherment of the BenAli diary: A preliminary statement. Journal of Negro History 25: $372-75$.

1940b. Some aspects of NegroMohammedan culture-contact among the Hausa. American Anthropologist 43: 51-61.

1941. Some problems in Hausa phonology. Language 17: 316-323. 
1946. The Influence of Islam on a Sudanese Religion. (Monographs of the American Ethnological Society, 10.) New York: J. J. Augustin.

1947a. Arabic loanwords in Hausa. Word 3: 85-97.

1947b. Islam and clan organization among the Hausa. Southwestern Journal of Anthropology 3: 193211.

1947c. Swahili prosody. Journal of the American Oriental Society 67: 24-30.

1948a. The classification of African languages. American Anthropologist 50: 24-30.

1948b. The tonal system of ProtoBantu. Word 4: 196-208.

1949a. Hausa verse prosody. Journal of the American Oriental Society 69: 125-35.

1949b. The Negro kingdom of the Sudan. Transactions of the New York Academy of Sciences, Series 2 11: $126-34$.

1949c. Studies in African linguistic classification: I. The Niger-Congo family. Southwestern Journal of Anthropology 5: 79-100.

1949d. Studies in African linguistic classification: II. The classification of Fulani. Southwestern Journal of Anthropology 5: 190-98.

1949e. Studies in African linguistic classification: III. The position of Bantu. Southwestern Journal of Anthropology 5: 309-17.

1950a. The patterning of root morphemes in Semitic. Word 6: 162-81.

1950b. Studies in African linguistic classification: IV. Hamito-Semitic. Southwestern Journal of Anthropology 6: 47-63.

1950c. Studies in African linguistic classification: V. The Eastern Sudanic family. Southwestern Journal of Anthropology 6: 143-60.

1950d. Studies in African linguistic classification: VI. The Click languages. Southwestern Journal of Anthropology 6: 223-37.

1950e. Studies in African linguistic classification: VII. Smaller families; index of languages. Southwestern Journal of Anthropology 6: 388-98.

1951. Vowel and nasal harmony in Bantu languages. Zaïre, Revue Congolaise 5(8): 813-20.

1952. The AfroAsiatic (HamitoSemitic) present. Journal of the American Oriental Society 72: 1-9, 167-68.

1953. An application of New World evidence to an African linguistic problem (Hausa). In Les AfroAméricains, pp. 129-31. (Mémoires de l'IFAN, 27.) Dakar: IFAN.

1954. Studies in African linguistic classification: VIII. Further remarks on method: revisions and corrections. Southwestern Journal of Anthropology 10: 405-15.

1955a. Internal a-plurals in Afroasiatic (HamitoSemitic). In Afrikanistische Studien, ed. by J. Lukas, pp. 198-204. Berlin: AkademieVerlag.

1955b. Studies in African Linguistic Classification. New Haven: Compass Publishing Company.

1957. Nilotic, 'NiloHamitic', and HamitoSemitic: A reply. Africa 27: 364-78.

1958. The labial consonants of ProtoAfroAsiatic. Word 14: 295-302.

1959a. Africa as a linguistic area. In Continuity and Change in African Cultures, ed. by W. R. Bascom and M. J. Herskovits, pp. 15-27. Chicago: University of Chicago Press.

1959b. The origin of the Masai passive. Africa 29: 171-76.

1960a. African tongues and tribes. Rotarian 96(35): 61-62.

1960b. An AfroAsiatic pattern of gender and number agreement. Journal of the American Oriental Society 80: 317-321.

1960c. Linguistic evidence for the influence of the Kanuri on the Hausa. Journal of African History 1: 205-12.

1960d. A method of measuring functional yield as applied to tone in African languages. Georgetown University Monograph Series on Language and Linguistics 12: 7-16.

1960e. A survey of African prosodic systems. In Culture in History, ed. by Stanley Diamond, pp. 925-50. New York: Columbia University Press.

1962a. Africa IV: Languages. In Encyclopedia Americana, 1: 223g-223h. New York.

1962b. The interpretation of the Coptic vowel system. Journal of African Languages 1: 22-29.

1962c. On the African affiliation of Hebrew and the Semitic languages. Jewish Social Studies 24 $79-85$. 


\section{Paul Newman}

1963a. History and present status of the Kwa problem. In Actes du Second Colloque International de Linguistique Négro-Africaine, ed. by Peter Ladefoged et. al., pp. 215-17. Dakar.

1963b. The Languages of Africa. (IJAL 29:1 Part II, Publication of the Indiana University Research Center in Anthropology, Folklore and Linguistics, 25.) Bloomington: Indiana University. (Reprinted with minor corrections, The Hague: Mouton (1966).)

1963c. Langues et histoire en Afrique. Présence Africaine 45: 35-45.

1963d. The Mogogodo, a forgotten Cushitic people. Journal of African Languages 2: 27-43.

1963e. Vowel harmony in African languages. In Actes du Second Colloque International de Linguistique Négro-Africaine, ed. by Peter Ladefoged et. al., pp. 33-37. Dakar.

1964a. Historical inferences from linguistic research in SubSaharan Africa. In Boston University Papers in African History, ed. by J. Butler, pp. 3-15. Boston: Boston University Press.

1964b. Reply to H. K. Schneider: Confusion in African linguistic classification. Current Anthropology 5: 56-57.

1964c. The study of language contact in Africa. In Symposium on Multilingualism, pp. 167-75. (CCTA/CSA Publications Bureau, 87.) London: CCTA/CSA.

1965a. The evidence for */mb/ as a Proto-Afroasiatic phoneme. In Symbolae Linguisticae in Honorem Georgii Kurylowicz, ed. by Adam Heinz et al., pp. 88-92. Cracow.

1965b. The history and present status of African linguistic studies. In Proceedings of the First International Congress of Africanists, Accra 1962, ed. by Michael Crowder and Lalage Bown, pp. 85-96. London: Longmans.

1965c. Linguistics. In The African World: A Survey of Social Research, ed. by Robert A. Lystad, pp. 416-41. New York: Praeger.

1965d. Urbanization, migration, and language. In Urbanization and Migration in West Africa, ed. by Hilda Kuper, pp. 50-59. Berkeley \& Los Angeles: University of California Press.

1966a. Interdisciplinary perspectives in African linguistic research. African Studies Bulletin (Hoover Institution) 9(1): 8-23.

1966b. Polyglotta evidence for consonant mutation in the Mandyak languages. Sierra Leone Language Review 5: 106-10.

1966c. (with Jack Berry) Sociolinguistic research in Africa. African Studies Bulletin (Hoover Institution) 9(2): 1-9.

1968a. Hausa. In Encyclopedia Britannica, 11: 163.

1968b. Nubian language and writing. In Encyclopedia Britannica, 16: 690-91.

1969. African languages. In Encyclopedia Britannica, 1: 312-14.

1970a. Chadic languages. In Encyclopedia Americana, 6: 231.

1970b. Cushitic languages. In Encyclopedia Americana, 8: 353.

1970c. Some generalizations concerning glottalic consonants, especially implosives. International Journal of American Linguistics 36: 123-45.

1972a. Linguistic evidence regarding Bantu origins. Journal of African History 13: 189-216.

1972b. On the identity of Jungraithmayr's Mimi. Africana Marburgensia 2: 45-49.

1974. Bantu and its closest relatives. In Papers from the Fifth Conference on African Linguistics, ed. by William R. Leben, pp. 115-19, 122-24. (Studies in African Linguistics, Supplement 5.) Los Angeles.

1977. Niger-Congo noun class markers: prefixes, suffixes, both or neither. In Papers from the Eighth Conference on African Linguistics, ed. by Martin Mould and Thomas J. Hinnebusch, pp. 97-104. (Studies in African Linguistics, Supplement 7.) Los Angeles.

1978. How does a language acquire gender markers? In Universals of Human Language. Vol. 3: Word Structure, ed. by J. H. Greenberg, pp. 47-82. Stanford: Stanford University Press.

1981. Nilo-Saharan moveable $k$ - as a stage III article (with a Penutian typological parallel). Journal of African Languages and Linguistics 3: 105-12.

1983. On some areal characteristics of African languages. In Current Approaches to African Linguistics (vol. 1), ed. by Ivan R. Dihoff, pp. 3-21. (Publications in African Languages and Linguistics, 8.) Dordrecht: Foris Publications. 
1999. Are there mixed languages? In Essays in Poetics, Literary History and Linguistics presented to Viacheslav Vsevolodovich Ivanov on the Occasion of His Seventieth Birthday, ed. by L. Fleishman et al., pp. 626-633. Moscow: OGI.

\section{Reviews}

1948. Review of The Cow-tail Switch and other West African Tales, by H. Courlander and G. Herzog. Journal of American Folklore 51: 99-100.

1949a. Review of Le Bura-Mabang du Ouadai, by Georges Trenga. American Anthropologist 51: 485-86.

1949b. Review of The Classification of the Bantu Languages, by Malcolm Guthrie. Word 5: 81-83.

1950a. Review of Africanisms in the Gullah dialect, by L. D. Turner. Journal of American Folklore 63 : 381-82.

1950b. Review of The Bantu of Northern Kavirondo, Vol. 1, by Gunter Wagner. American Anthropologist 52: 255-56.

1950c. Review of The Distribution of the Nilotic and Nilo-Hamitic Languages of Africa, by M. A. Bryan. Language 26: 173-75.

1950d. Review of The Negro-African Languages, by L. Homburger. Language 26: 170-73.

1951a. Review of Grundzüge einer vergleichenden Grammatik der Bantusprachen, by Carl Meinhof. Journal of the American Oriental Society 71: 94-95.

1951b. Review of Manuel de Tschiluba (Kasayi, Congo Belge), by A. Burssens. Language 27: 438-39.

1951c. Review of Wörterbuch der Djaga-Sprache (Madjame-Mundari) gesprochen am Kilimandjaro in Ostafrika, by Emil Müller. Journal of the American Oriental Society 71: 194.

1952. Review of The Sculpture of Negro Africa, by Paul S. Wingert. Journal of American Folklore 65: 104-5.

1953a. Review of Dictionnaire Ngbandi, by P. B. Lekens, and Dictionnaire Français-Lomongo, by H. Hulstaert. Language 29: 576-77.

1953b. Review of Recueil de textes Falashas, by A. E. Aescoly. American Anthropologist 55: 445.

1953c. Review of The Ethnographic Survey of Africa. American Anthropologist 55: 162-63.

1954a. Review of La langue berbère, by A. Basset. American Anthropologist 56: 148.

1954b. Review of Languages of West Africa, by D. Westermann and M. A. Bryan. Language 30: $302-9$.

1955a. Review of Baba of Kano: A Woman of the Moslem Hausa, by Mary F. Smith. American Anthropologist 58: 749-50.

1955b. Review of The Economy of Hausa Communities of Zaria, by M. G. Smith. American Anthropologist 58: 932-33.

1956a. Review of A Maasai Grammar with Vocabular, by A. N. Tucker and J. T. ole Mpaayei. Word 12: 487-89.

1956b. Review of Geschichte der Erforschung der Nilotischen Sprachen, by Oswin Köhler. Language 32: 563-67.

1957. Review of A Bushman Dictionary, by Dorothea F. Bleek. Language 33: 495-97.

1959. Review of A Short Description of Item Categories in Iraqw, by W. H. Whiteley. American Anthropologist 61: 163-64.

1961. Review of Hausa Literature and the Hausa Sound System and The Language of the Hausa People, by R. C. Abraham. American Anthropologist 63: 452.

1969. Review of The Problems in the Classification of the African Languages, by István Fodor. Language 45: 427-32.

1996. Review of Hamito-Semitic Etymological Dictionary, by V. E. Orel and Olga V. Stolbova. Anthropological Linguistics 38: 550-56. 